ҚАЗАҚСТАН РЕСПУБЛИКАСЫ

ҰЛТТЫҚ ҒЫЛЫМ АКАДЕМИЯСЫНЫН

АБАЙ АТЫНДАҒЫ ҚАЗАҚ ҰЛТТЫҚ

ПЕДАГОГИКАЛЫҚ УНИВЕРСИТЕТІНІҢ

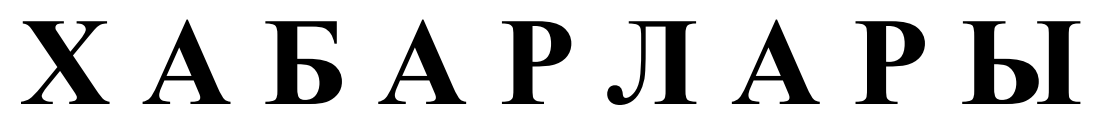

\section{ИЗВЕСТИЯ}

НАЦИОНАЛЬНОЙ АКАДЕМИИ НАУК РЕСПУБЛИКИ КАЗАХСТАН

КАЗАХСКИЙ НАЦИОНАЛЬНЫЙ

ПЕДАГОГИЧЕСКИЙ УНИВЕРСИТЕТ ИМ. АБАЯ

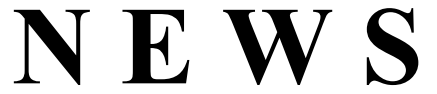

OF THE NATIONAL ACADEMY OF SCIENCES OF THE REPUBLIC OF KAZAKHSTAN

ABAY KAZAKH NATIONAL PEDAGOGICAL UNIVERSITY

ҚОҒАМДЫҚ ЖӘНЕ ГУМАНИТАРЛЫҚ ҒЫЛЫМДАР СЕРИЯСЫ

СЕРИЯ ОБЩЕСТВЕННЫХ И ГУМАНИТАРНЫХ НАУК

$\checkmark$

SERIES OF SOCIAL AND HUMAN SCIENCES

$$
5 \text { (321) }
$$

КЫРКУЙЕК - КАЗАН 2018 ж.

СЕНТЯБРЬ - ОКТЯБРЬ 2018 Г.

SEPTEMBER - OCTOBER 2018

1962 ЖЫЛДЫҢ ҚАНТАР АЙЫНАН ШЫҒА БАСТАҒАН

ИЗДАЕТСЯ С ЯНВАРЯ 1962 ГОДА

PUBLISHED SINCE JANUARY 1962

ЖЫЛЫНА 6 РЕТ ШЫҒАДЫ

ВЫХОДИТ 6 РАЗ В ГОД

PUBLISHED 6 TIMES A YEAR 
Ба с ре дактор

ҚР ҰҒА кұрметті мүшесі

Балықбаев Т.O.

Р е д а ц и я а лқ а сы:

экон. ғ. докторы, проф., ҚР ҰҒА академигі Баймұратов У.Б.; тарих ғ. докторы, проф., ҚР ҰҒА академигі Байпақов К.М.; филос. ғ.докторы, проф., ҚР ҰҒА академигі Есім Г.Е.; фил. ғ. докторы,, проф., ҚР ҰҒА академигі Қирабаев С.С.; эк. ғ. докторы, проф., ҚР ҰҒА академигі Кошанов А.К.; эк.ғ. докторы, проф., ҚР ҰҒА академигі Нәрібаев К.Н. (бас редактордың орынбасары); филос. ғ.докторы, проф., ҚР ҰҒА академигі Нысанбаев А.Н.; заң ғ. докторы, проф., ҚР ҰҒА академигі Сәбікенов С.Н.; заң ғ. докторы, проф., ҚР ҰҒА академигі Сүлейменов М.К.; эк. ғ. докторы, проф., ҚР ҰҒА академигі Сатыбалдин С.С.; тарих ғ. докторы, проф., ҚР ҰҒА академик Әбжанов Х.М.; тарих ғ. докторы, проф., ҚР ҰҒА корр. мүшесі Әбусеитова М.Х.; тарих ғ. докторы, проф., ҚР ҰҒА академик Байтанаев Б.А.; филол. ғ. докторы, проф., ҚР ҰҒА корр. мүшесі Жақып Б.А.; фил. ғ. докторы, проф., академик НАН РК Қалижанов У.К.; филол. ғ. докторы, проф., ҚР ҰҒА академик Қамзабекұлы Д.; тарих ғ. докторы, проф., ҚР ҰҒА академик Қожамжарова Д.П.; тарих ғ. докторы, проф., ҚР ҰҒА академик Койгелдиев М.К.; фил. ғ. докторы, проф., ҚР ҰҒА корр. мүшесі Кұрманбайұлы Ш.; тарих ғ. докторы, проф., ҚР ҰҒА корр. мүшесі Таймағанбетов Ж.К.; социол. ғ. докторы, проф., ҚР ҰҒА корр. мүшесі Шәукенова 3.К.; фил. ғ. докторы, проф., КР ҰҒА корр. мүшесі Дербісәлі А.; саяси. ғ. докторы, проф., Бижанов А.К., тарих ғ. докторы, проф., Кабульдинов 3.Е.; фил. ғ. докторы, проф., ҚР ҰҒА корр мүшесі Қажыбек Е.3.

\section{Р едакция ке н е с i:}

Молдова Республикасының ҰҒА академигі Белостечник Г. (Молдова); Әзірбайжан ҰҒА академигі Велиханлы Н. (Азербайджан); Тәжікстан ҰҒА академигі Назаров Т.Н. (Тәжікстан); Молдова Республикасының ҰҒА академигі Рошка А. (Молдова); Молдова Республикасының ҰҒА академигі Руснак Г. (Молдова); Әзірбайжан ҰҒА корр. мүшесі Мурадов Ш. (Әзірбайжан); Әзірбайжан ҰҒА корр. мүшесі Сафарова 3. (Әзірбайжан); э. ғ. д., проф. Василенко В.Н. (Украина); заң ғ. докт., проф. Устименко В.А. (Украина)

«Қазақстан Республикасы Ұлттық ғылым академиясының Хабарлары. Қоғамдық және гуманитарлық ғылымдар сериясы». ISSN 2224-5294

Меншіктенуші: «Қазақстан Республикасының Ұлттық ғылым академиясы» РҚБ (Алматы қ.)

Қазақстан республикасының Мәдениет пен ақпарат министрлігінің Ақпарат және мұрағат комитетінде 30.04.2010 ж. берілген № 10894-Ж мерзімдік басылым тіркеуіне қойылу туралы куәлік

Мерзімділігі: жылына 6 рет.

Тиражы: 500 дана.

Редакцияның мекенжайы: 050010, Алматы қ., Шевченко көш., 28, 219 бөл., 220, тел.: 272-13-19, 272-13-18, http://nauka-nanrk.kz. social-human.kz

(C) Қазақстан Республикасының Ұлттық ғылым академиясы, 2018

Типографияның мекенжайы: «Аруна» ЖК, Алматы қ., Муратбаева көш., 75. 
Главный редакто $p$

Почетный член НАН РК

T.O. Балыкбаев

Р е дак ци онн а я коллег и я:

докт. экон. Н., проф., академик НАН РК У.Б. Баймуратов; докт. ист. н., проф., академик НАН РК К.М. Байпаков; докт. филос. Н., проф., академик НАН РК Г.Е. Есим; докт. фил. Н., проф., академик НАН РК С.С. Кирабаев; докт. экон. Н., проф., академик НАН РК А.К. Кошанов; докт. экон. Н., проф., академик НАН РК К.Н. Нарибаев (заместитель главного редактора); докт. филос. н., проф., академик НАН РК А.Н. Нысанбаев; докт. юр. Н., проф., академик НАН РК С.Н. Сабикенов; докт. юр. н., проф., академик НАН РК М.К. Сулейменов; докт. экон. Н., проф., академик НАН РК С.С. Сатубалдин; докт. ист. н., проф., академик НАН РК Х.М. Абжанов; докт. ист. н., проф., чл.-корр. НАН РК М.Х. Абусеитова; докт. ист. н., проф., академик НАН РК Б.А. Байтанаев; докт. фил. н., проф., чл.-корр. НАН РК Б.А. Жакып; докт. фиолол. н., проф., академик НАН РК У.К. Калижанов; докт. фил. н., проф., академик НАН РК Д. Камзабекулы; докт. ист. н., проф., академик НАН РК Д.П. Кожамжарова; докт. ист. н., проф., академик НАН РК М.К. Койгельдиев; докт. филол. н., проф., чл.-корр. НАН РК Ш. Курманбайулы; докт. ист. н., проф., чл.корр. НАН РК Ж.К. Таймаганбетов; докт. социол. н., проф., чл.-корр. НАН РК З.К. Шаукенова; д. филол. н., проф., чл.-корр. НАН РК А. Дербисали; доктор политических наук, проф., Бижанов А.К.; доктор ист. наук, проф., Кабульдинов 3.Е.; доктор филол. н., проф., член-корр. НАН РК Қажыбек Е.3.

Р е дак ци онны й с ов е т

академик НАН Республики Молдова Г. Белостечник (Молдова); академик НАН Азербайджанской Республики Н. Велиханлы (Азербайджан); академик НАН Республики Таджикистан Т.Н. Назаров (Таджикистан); академик НАН Республики Молдова А. Рошка (Молдова); академик НАН Республики Молдова Г. Руснак (Молдова); чл.-корр. НАН Азербайджанской Республики Ш. Мурадов (Азербайджан), член-корр. НАН Азербайджанской Республики 3.Сафарова (Азербайджан); д. э. н., проф. В.Н. Василенко (Украина); д.ю.н., проф. В.А. Устименко (Украина)

Известия Национальной академии наук Республики Казахстан. Серия общественных и гуманитарных наук. ISSN 2224-5294

Собственник: РОО «Национальная академия наук Республики Казахстан» (г. Алматы)

Свидетельство о постановке на учет периодического печатного издания в Комитете информации и архивов

Министерства культуры и информации Республики Казахстан № 10894-Ж, выданное 30.04.2010 г.

Периодичность 6 раз в год

Тираж: 500 экземпляров

Адрес редакции: 050010, г. Алматы, ул. Шевченко, 28, ком. 219, 220, тел. 272-13-19, 272-13-18, www:nauka-nanrk.kz / social-human.kz

(C) Национальная академия наук Республики Казахстан, 2018 г.

Адрес типографии: ИП «Аруна», г. Алматы, ул. Муратбаева, 75

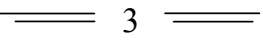


Chief Editor

\section{Honorary member of NAS RK \\ Balykbayev T.O}

Editorial board:

Doctor of economics, prof, academician of NAS RK Baimuratov U.B.; doctor of history, prof, academician of NAS RK Baipakov K.M.; doctor of philosophy, prof, academician of NAS RK Esim G.E.; doctor of philology, prof, academician of NAS RK Kirabayev S.S.; doctor of economics, prof, academician of NAS RK Koshanov A.K.; doctor of economics, prof, academician of NAS RK Naribayev K.N. (deputy editor-in-chief); doctor of philosophy, prof, academician of NAS RK Nyssanbayev A.N.; doctor of law, prof, academician of NAS RK Sabikenov S.N.; doctor of law, prof, academician of NAS RK Suleymenov M.K.; doctor of economy, prof, academician of NAS RK Satybaldin S.S.; doctor of history, prof, academician of NAS RK Abzhanov H.M; doctor of history, prof, corresponding member of NAS RK Abuseitova M.H.; doctor of history, prof, academician of NAS RK Baitanaev B.A.; doctor of philology, prof, corresponding member of NAS RK Zhakyp B.A.; doctor of philology, prof, academician of NAS RK Kalizhanov U.K.; doctor of philology, prof, academician of NAS RK Hamzabekuly D.; doctor of history, prof, academician of NAS RK Kozhamzharova D.P.; doctor of history, prof, academician of NAS RK Koigeldiev M.K.; doctor of philology, prof, corresponding member of NAS RK Kurmanbaiuly Sh.; doctor of history, prof, academician of NAS RK Taimaganbetov J.K.; doctor of sociology, prof, corresponding member of NAS RK Shaukenova Z.K.; doctor of philology, prof, corresponding member of NAS RK Derbisali A.; doctor of political science, prof Bizhanov A.K; doctor of History, prof Kabuldinov Z.E.; doctor of philology, prof, corresponding member of NAS RK Kazhybek E.Z.

\section{Editorial staff:}

Academician NAS Republic of Moldova Belostechnik.G (Moldova); Academician NAS Republic of Azerbaijan Velikhanli N. (Azerbaijan); Academician NAS Republic of Tajikistan Nazarov T.N. (Tajikistan); Academician NAS Republic of Moldova Roshka A. (Moldova) Academician NAS Republic of Moldova Rusnak G. (Moldova); Corresponding member of the NAS Republic of Azerbaijan Muradov Sh. (Azerbaijan); Corresponding member of the NAS Republic of Azerbaijan Safarova Z. (Azerbaijan); Associate professor of Economics Vasilenko V.N. (Ukraine), Associate professor of Law Ustimenko V.A. (Ukraine)

News of the National Academy of Sciences of the Republic of Kazakhstan. Series of Social and Humanities. ISSN 2224-5294

Owner: RPA "National Academy of Sciences of the Republic of Kazakhstan" (Almaty)

The certificate of registration of a periodic printed publication in the Committee of information and archives of the Ministry of culture and information of the Republic of Kazakhstan N 10894-Ж, issued 30.04.2010

Periodicity: 6 times a year

Circulation: 500 copies

Editorial address: 28, Shevchenko str., of. 219, 220, Almaty, 050010, tel. 272-13-19, 272-13-18, www:nauka-nanrk.kz / social-human.kz

(C) National Academy of Sciences of the Republic of Kazakhstan, 2018

Address of printing house: ST "Aruna", 75, Muratbayev str, Almaty 
N E W S

OF THE NATIONAL ACADEMY OF SCIENCES OF THE REPUBLIC OF KAZAKHSTAN

SERIES OF SOCIAL AND HUMAN SCIENCES

ISSN 2224-5294

https://doi.org/10.32014/2018.2224-5294.13

Volume 5, Number 321 (2018), 73 - 78

UDC: 330.14 .014

A. Zh. Eskalieva ${ }^{1}$, M.T. Baymukhanova ${ }^{2}$, D.O. Ahmurzina ${ }^{3}$

${ }^{2,3}$ Pavlodar State University named after S. Toraigyrov;

${ }^{1}$ Atyrau State University named after H.Dosmukhamedov assel2704@mail.ru, Aiko-er@mail.ru, Zhanna81@mail.ru

\title{
PERSPECTIVES OF STRENGTHENING THE QUALITY OF THE HUMAN CAPITAL OF THE SOCIAL SPHERE
}

\begin{abstract}
In the authors' opinion, the role of a person with his excellent education, high qualification and experience in ensuring economic growth and increasing the competitiveness of the state is growing. Work in the Republic of Kazakhstan is of a very low quality, the evidence of which is the production of most domestic enterprises that are not competitive in world markets. Low-productivity and low-quality labor significantly reduces the accumulated Kazakhstan's human capital. The idea and practice of the reproduction and functioning of human capital is constantly complicated and filled with new content. At the same time, human capital receives recognition and development in rather wide values - from the individual to the world community. Human capital, becoming a mass phenomenon, corresponds to the innovative type of reproduction. Perhaps that is why in recent years Kazakhstan's leadership has turned to the task of forming national human capital, because the country needs tools that can provide a transition to an innovative type of reproduction.

Keywords: human capital, the formation of human capital, the quality of human capital, national competitiveness, competitive advantages.

\section{INTRODUCTION}

Recently, much attention has been paid to the problem of the formation of human capital. In economics, a person is viewed not only as a production factor - a labor resource, but also its qualitative characteristics, that is, human capital. Human capital must be viewed as a new effective resource that is important for social and economic development of society and the state on the basis of its qualitative and quantitative growth in all areas and structures of society and the state. The main goal of human capital, as well as of all material forms of capital, is profit, a reduction in production costs and an increase in labor productivity. Human capital includes three components: - Biophysical capital, which characterizes the physical and psychological health of a person; - social (spiritual) capital, which characterizes man as the bearer of culture and morality, as well as the level of his education and the potential for his social interaction; - intellectual capital, which characterizes the knowledge, information and creativity of a person. The urgency of the issue of the formation of human capital is determined by contemporary realities of world social and economic development.
\end{abstract}

\section{MAIN PART}

Now the state allocates significant funds to support external factors of human development and fulfillment of its social obligations to society (payment of pensions, maternity capital, unemployment benefits, etc.). All this contributes to an increase in the level and quality of life of the people of Kazakhstan, as well as human capital in general. But, despite some improvements, in the Republic of Kazakhstan there is a degradation of the population, caused by a significant decrease in the level of his health and intellectual level. Great problems for the formation of human capital create an outdated way of life and worldview, low efficiency and inability and unwillingness to adapt to new conditions [1]. 
Human capital in Kazakhstan is becoming obsolete along with its carriers. For the transition to an innovative socio-economic system, for the growth of national wealth and all its components, it is necessary to create mechanisms that can qualitatively and quantitatively change human capital, because today human capital is viewed as a necessary condition for all processes of society and state life. It is one of the main components of the country's long-term economic growth. Awareness of this requires the adoption of complex decisions that form human capital in the state, society and individual companies, which ensure both sustainable economic growth and the achievement of a higher level of the well-being of the population and a decent quality of life [1].

Kazakhstan is building a new development strategy that takes into account the global context that has changed in recent years. In general, this strategy is formulated in the Address of the President of the Republic of Kazakhstan N.A. Nazarbayev Strategy "Kazakhstan - 2050": a new political course of the state ". The solution of the tasks set in President Nursultan Nazarbayev's Address to the Nation of Kazakhstan "The Way to the Future", overcoming global challenges, achieving sustainable development requires the development of scientifically sound approaches to the formation of a new quality of human capital as the driving force of global development. National competitiveness is an instrument in the struggle for a place in the world economic system. The issue of improving the competitiveness of the republic's economy is key to the development of the Kazakhstan-2050 Strategy [2], Strategy-2030 [3], the Strategic Development Plan of the Republic of Kazakhstan until 2020 [4] and other programs aimed at modernizing the economy. The successful modernization of the republic's economy is predetermined achievements in the formation of human capital as the main factor in enhancing the competitiveness of the national economy.

The application of the socio-economic approach in the general framework of research on the management of human capital should be noted the fact of eliminating subjectivity in sociological research in interpreting received sociological and statistical data. Relying on the Heisenberg uncertainty principle, according to which the observed object changes due to a fact of observation that distorts the experiment, i.e. it is possible to state that many actual (sociological and statistical) data are largely subjective and do not reflect actual social interactions and their effects [5].

Thus, the main logos of the social and economic approach is the premise that human behavior must be presented as a holistic, which in its integrative, productive characterization maximizes character, which inevitably entails both a preference for stability over instability and a preference for equilibrium before imbalance. Such a holistic outline of the theoretical and methodological design of research on human capital management in highly competitive conditions allows eliminating both subjective conclusions and those considered ad hoc hypotheses, preferences in explanations from intellectuals.

The study of structural capital and its types, types and relations with human capital is one of the theoretical and methodological cross-cutting themes of this work. Since it is clear that human capital is impossible neither ontological nor sociological, without society and without the conditions for the creation and realization of human capital, it becomes clear that structural capital is a necessary social (national, corporate) complex institution that, with one - undoubtedly, is an indicator of the development of society, and on the other hand, it ensures the development of human capital. This sequence reveals a phasedtemporal characterization of the theoretical and methodological construct of the study of human capital management in modern highly competitive conditions, not only in the economic sphere, but also in the sphere of national security [6].

Structural capital as part of the theoretical and methodological construct of research thus includes: 1) a phased-temporal characterization of the formation of human capital; 2) the social characteristics of the conditions under which productive human capital is possible; 3) the characteristics of human capital, under which the conditions of national security in modern civilizational conditions are ensured; 4) the level of social comfort as every individual offering his human capital for rent on the labor market, and for social groups and society as a whole (political level); 5) The level of rationalization and optimization of styles and approaches of concrete management of human capital [7].

Thus, it is shown that the study of human capital must inevitably begin within the framework of institutional socio-economic theory as a transdisciplinary synthesis of sociology and economic theory. Such a requirement for the proposed theoretical and methodological construct is explained by the 
synergetic effect that is achieved thanks to the developed theory within the institutional economy and the explanatory interpretation effect achieved through the use of categories of sociology of management.

In addition, the shown theoretical and methodological tools of the analysis of human capital management allow us to reveal the possibilities of representing human capital not only at the operational level, but also at the levels of action and activity [7].

The low quality of training is due to the low level of funding for education and science, as well as the narrow range of its sources, the shortage of qualified personnel, the separation of the system of training personnel from real practice, the limited motivation of teachers' work and the teaching staff of higher education institutions, production and education, inadequate participation of employers in the formation of the content of educational programs, ineffective use of it scientific potential and others [8].

ensure the effectiveness of investments in the development and implementation of human capital can be provided that the following conditions:

- the effectiveness of the economy as a system;

- minimum administrative regulation of the economy;

- formation of competitive domestic markets;

- attraction of capital;

- ensuring the ownership of investors;

\begin{tabular}{|c|}
\hline The mechanism of formation and development of national human capital \\
\hline$\downarrow$ \\
\hline Value benchmarks \\
$\downarrow$ \\
\hline Source of development of human capital \\
\hline \\
\hline Formation of human capital adequate to the requirements of the new economy \\
\hline$\downarrow$ \\
\hline Levels of creation of conditions for the development of human capital \\
\hline$\downarrow$ \\
\hline Mini-level (individual, household) \\
\hline Microlevel (enterprise) \\
\hline$\downarrow$ \\
\hline Meso level (region) \\
\hline$\downarrow$ \\
\hline Macro level (state) \\
\hline$\downarrow$ \\
\hline Mega-level (world community) \\
\hline$\downarrow$ \\
\hline Complicating Human Capital \\
\hline$\downarrow$ \\
\hline Contradictions arising in the sphere of socio-economic relations \\
\hline$\downarrow$ \\
\hline Equity of human capital \\
\hline$\downarrow$ \\
\hline Dynamics of human capital \\
\hline$\downarrow$ \\
\hline Concility of human resources \\
\hline$\downarrow$ \\
\hline
\end{tabular}


Известия Наџиональной Академии наук Республики Казахстан

\begin{tabular}{|c|}
\hline \hline Self-regulation of human capital \\
$\downarrow$ \\
\hline A set of measures for the development of human capital \\
$\downarrow$ \\
\hline Continuity, purposefulness, efficiency of investment in human capital \\
$\downarrow$ \\
\hline Taking into account the interests and motivation of the subjects of the economy \\
\hline Social responsibility of the state \\
\hline$\downarrow$ \\
\hline Result \\
\hline \\
\hline $\begin{array}{c}\text { Coordination of interests of various subjects of the economy in the process of human capital } \\
\text { development }\end{array}$ \\
\hline
\end{tabular}

Figure 1 - The mechanism of the development of national human capital in the conditions of building an innovative economy

- increase in the share of expenditures for financing the social sphere, science, education, health, culture to the level corresponding to the indicators of developed countries;

- increase in the remuneration of labor in the public sector, in particular doctors, teachers, to the average wage level in non-state organizations;

- implementation of state targeted investment programs in the healthcare, education, science, culture, information technology development with the strengthening of the monitoring and control system.

It should be remembered that modern human capital is an intensive productive and social factor of development and life activity of the subject, which is inextricably linked with the person, with his intellect and mentality. It is formed due to investments in education, education, health, knowledge, entrepreneurial ability, information support, security and economic freedom of the population, as well as in science, culture and art.

In developed countries, public spending on higher education is up to $2.6 \%$ of gross domestic product (USA, South Korea). While in Kazakhstan, this figure does not exceed 0.2\%. [9]. The low level of financing for the education sector has led to a lack of development of the material and technical base of education, information and modern technologies, and a decrease in the motivation of teachers, teachers and researchers. In the structure of the income of higher educational institutions, $80 \%$ is tuition fees. Whereas funds of public funds, philanthropic and donor donations, scientific research for business structures and other non-state sources act as sources of income for higher education institutions in European countries. For example, in UK universities, tuition fees are $15-25 \%$ of the total budget, $6 \%$ research for business and other structures, 3\% - funds from the European Union and public funds, 5\% philanthropic and donor donations through tuition fees , 4\% - incomes from paid services, the rest part public funds and other non-state sources [8].

\section{CONCLUSION}

Formation and implementation of human capital should be included in the strategic planning system and be determined on the basis of macroeconomic forecasts in close connection with the planning of development of all sectors of the economy and specific enterprises and regions. It seems that the issue of ensuring the economy with labor resources should be included in the category of issues related to the national security of Kazakhstan [9].

At a time when the world entered a post-industrial era of the formation and development of an "intelligent" economy, human capital becomes a strategic resource of the country, whose quality in the aspect of intelligence, education and qualification plays a leading role in creating a competitive economy. This largely changes the nature of competition in world markets and determines the country's place in the international division of labor [10]. 
Social policy is also understood as a purposeful activity of the state on the redistribution of resources among citizens with a view to achieving prosperity. Usually in international practice, speaking about social policy, mention such areas as social security, health, education, housing and employment. Social welfare in the Western tradition is understood as a system of measures to protect the individual and the family from those risks that can not be avoided, including from the serious reduction in income necessary to maintain an acceptable standard of living.

\title{
REFERENCES
}

[1] Obukhova LS Problems of Human Capital Formation in Russia // Young Scientist. - 2010. - №7. - P. 119-121. - URL https://moluch.ru/archive/18/1863/ (reference date: September 13, 2018).

[2] Nazarbayev N. And. Kazakhstan's way - 2050: common goal, common interests, common future. The President's message to the people of Kazakhstan. Astana, 17 January 2014. // www.akorda.kz

[3] Strategy 2030. State program of development // www.kazembassy / strategy_2030.html

[4] Omarkhanova Zh., Integration of Financial Markets under the Conditions of the Eurasian Economic Union / Ed. Journal of Advanced Research in Law and Economics, [S.1.], v. 8, n. 6, p. 1779-1784, mar. 2018. ISSN 2068-696. (in English)

[5] Sabirova R.K., Baimukhasheva M.K., Utepkalieva K.M., Dingaziyeva M.D., Sanaliyeva L.K., Tsatkhlanova T.T. Intellectual potential as a basis for the formation of the innovative economy of the Republic of Kazakhstan. Bulletin of the National Academy of Sciences of the Republic of Kazakhstan ". No. 3. 2018 P.192-197, ISSN 1991-3494 (in English)

[6] Sabirova R.K., Adietova E.M., Utalieva RS., Bisembieva Zh.K., Mugauina R.V., Kaigorodtsev A. DEVELOPMENT OF THE LABOR MARKET OF THE REPUBLIC OF KAZAKHSTAN IN THE CONDITIONS OF INNOVATIVE ECONOMY. "Bulletin of the National Academy of Sciences

[7] Zhansagimova A.E., Perfection of management of a manpower. Bulletin of Turan №2, 2015. ISSN 1562-2959 (In Russian)

[8] Education at a Glance: OECD Indicators, 2011.

[9] Kazakhstan 2017. Statistically ginamarie / Editor A.A.Smayilov. Astana, 2017. 485 p.

[10]Aubakirov YA, Maydyrova AB The role of man as a productive force in the labor market // Vestnik KazNU. Al-Farabi . 2002. No. 1 (29) . P.41-43. ISBN 978-601-04-2045-8 (In English).

УДК: 330.14 .014

\author{
А. Ж. Ескалиева ${ }^{1}$, М.Т. Баймуханова ${ }^{2}$, Д.О. Ахмурзина ${ }^{3}$ \\ ${ }^{2,3}$ Павлодарский государственный университет имени С.Торайгырова; \\ ${ }^{1}$ Атырауский Государственный унив им Х.Досмухамедова

\section{ПЕРСПЕКТИВЫ УСИЛЕНИЯ КАЧЕСТВА ЧЕЛОВЕЧЕСКОГО КАПИТАЛА СОЦИАЛЬНОЙ СФЕРЫ}

Аннотация. По мнению авторов возрастает роль человека с его прекрасным образованием, высокой квалификацией и опытом в обеспечении экономического роста и повышении конкурентоспособности государства. Труд в РК весьма низкого качества, свидетельством чегоявляется продукция большинства отечественных предприятий, неконкурентоспособных на мировых рынках. Низкопроизводительный и некачественный труд существенно снижает накопленный казахстанский человеческий капитал. Идея и практика воспроизводства и функционирования человеческого капитала постоянно усложняются и наполняются новым содержанием. При этом человеческий капитал получает признание и развитие в довольно широких значениях - от индивида до мирового сообщества. Человеческий капитал, став массовым феноменом, соответствует инновационному типу воспроизводства.Возможно поэтому в последние годы руководство Казахстана обратилось к задаче формирования национального человеческого капитала, поскольку стране нужны инструменты, способные обеспечить переход к инновационномутипу воспроизводства.

Ключевые слова: человеческий капитал, формирование человеческого капитала, качество человеческого капитала, национальная конкурентоспособность, конкурентные преимущества 
УДК: 330.14 .014

\author{
А. Ж. Ескалиева ${ }^{1}$, М.Т. Баймуханова ${ }^{2}$, Д.О. Ахмурзина ${ }^{3}$ \\ ${ }^{2,3}$ С.Торайғыров атындағы Павлодар мемлекеттік университеті; \\ ${ }^{1}$ Х.Досмұхамедов атындағы Атырау мемлекеттік университеті
}

\title{
ӘЛЕУМЕТТІК САЛА АДАМ КАПИТАЛЫНЫҢ САПАСЫН ҚОЛДАУДЫҢ ПЕРСПЕКТИВАЛАРЫ
}

Аннотация. Авторлардың пікірі бойынша, адамның жоғары білімімен, жоғары біліктілігімен және экономикалық өсуді қамтамасыз етудегі және мемлекеттің бәсекеге қабілеттілігін арттырудағы тәжірибесі өсіп келеді. Қазақстан Республикасында жұмыс сапасы өте төмен, оның дәлелі әлемдік нарықта бәсекеге қабілетті емес көптеген отандық кәсіпорындардың өндірісі болып табылады. Төмен өнімділік және сапасыз еңбек жинақталған Қазақстанның адам капиталын айтарлықтай төмендетеді. Адам капиталын жаңғырту мен жұмыс істеу идеясы мен практикасы үнемі күрделі және жаңа мазмұнмен толтырылады. Сонымен қатар, адам капиталы танымалдылық пен дамуды кең адамдық құндылықтармен - жеке адамнан әлемдік қоғамдастыққа дейін алады. Адамзат капиталы бұқаралық құбылысқа айналып, жаңашылдықтың жаңашыл түріне сай келеді. Бұл себепті соңғы жылдары қазақстандық басшылық ұлттық адами капиталды қалыптастыру міндетіне айналды, себебі, елде жаңғыртудың инновациялық түріне көшуді қамтамасыз ететін құралдар қажет.

Түйін сөздер: адами капитал, бәсекелестік артықшылықтар, адами капиталды қалыптастыру, адами капитал сапасы ұлттық бәсекеге қабілеттілік

Information about author:

Eskalieva A. Zh. - Pavlodar State University named after S. Toraigyrov; https://orcid.org/0000 000205290575 ;

Baymukhanova M.T. - Atyrau State University named after H.Dosmukhamedov, https://orcid.org/0000-0001-5095-6754;

Ahmurzina D.O. - Atyrau State University named after H.Dosmukhamedov, https://orcid.org/0000-0001-8616-9939 


\section{МАЗМҰНЫ}

Алтыбаева С.М., Савындыков Е.С. Көркем мәтін құрылымындағы мифопоэтикалық модельдеу және мәдени код...... 5 Сембиева Л.М., Мажитов Д.М., Карпиикая М.Е., Хамитова Д.М. Экономиканы жаңғырту жағдайындағы ЕАЭО елдерінің монетарлық жүесінін өзгеруі .....

Құлсариева А.Т., Султанова М.Э., Шайгозова Ж.Н. Фольклор және сәйкестілік: Қазақстанның қазіргі заманғы

мәдениетіндегі тарих, жады және аңыз шығармашылығы ........................................................................................... 19

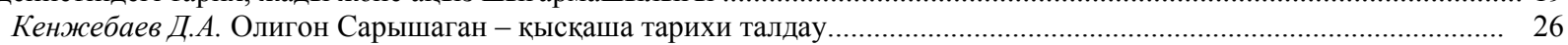

АбдулинаГ.А., БазарбаевА.Г. Ұйымдардағы адам ресурстарын басқарудың заманауи тұжырымдамалары................ 33

Авыбаев А.Н., Адибаева А.К. Геноцид туралы БҰҰ Конвенциясының қатысушы мемлекеттердің қылмыстық

заңнамаларындағы имплементациялық тетіктері: жалпы салыстырмалы талдау............................................................ 39

Ахметжанов Б., Тәжібекова К.Б., Шаметова А.А. Қазақстан көлік өнеркәсіптің дамуын талдау............................. 44

Аюпова 3.К., Құсайынов Д.Ө. Тәуелсіздік жағдайындағы қазақстан республикасының конституциялық-құқықтық

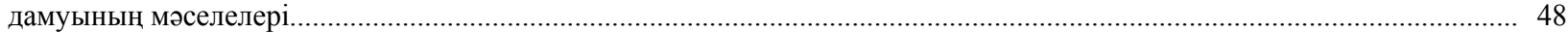

Нурпеисова А.А., Рей И.Ю., Бижанов Д.Т., Тлеужанова Д.А. Инновациялық өндірісді жасаудың процесін

бақылауының негізгі элементтері

Гиздатов Г.Г. Қазақстандық дискурсының құрылымы психолингвистиякалық зерттеу .

Ищанова Р.К. Мемлекеттік шығындарды басқару - мемлекеттің қаржылық тұрақтылығын қамтамасыз ету.............. 64

Мадышева А.М. Бикенова А.С., Елеусиз Л.Т. Білім саласындағы туристік қызметтер............................................. 68

Ескалиева А. Ж., Баймуханова М.Т., Ахмурзина Д.О. Әлеуметтік сала адам капиталының сапасын қолдаудың

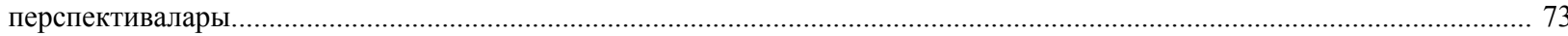

Мархаева Б.А., Козбахова Д.Л. Жауапкершілік орталық және трансферттік баға белгілеу............................................ 79

Сабирова Р.К., Утепкалиева К.М., Кабаков С.Б. Қазақстандағы ауыл шаруашылығы экономикасының

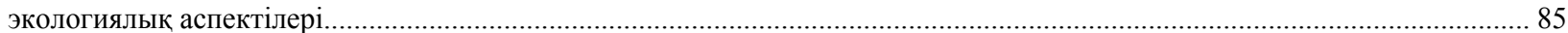

Тлесова Э., Хойч А., Кураш Н. Қазақстан республикасының ғылыми инновациялық потенциясы және оның

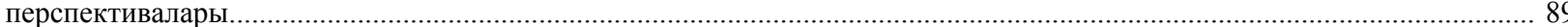

Хамитхан Н. Қазақстандағы банктік қызметтердің сапасын жақсарту жағдайында банкаралык басекелестік............ 95

Шалдарбеков Қ.Б., Муханова Г.С., Нурмухамбетова 3.С. Аймақтарды дамыту бағдарламаларын жүзеге асырудағы жобалық басқаруды қолданудың шетелдік тәжірибесі

КаратаеваА.М., Бердиярова Ж.С. Мемлекеттік қызметшінің әдептік мәдениеті және құқықтық мәдениеті

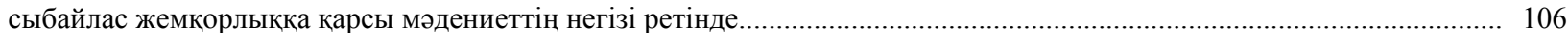

Алдабергенова А.А. Абсурд әдебиетін аударудың лингвомәдени аспектілері ................................................... 113

Стукач В. Ф., Байдалинова А. С., Сандыбаева Б. А. Қазақстанның қаржылық қауіпсіздігі......................................... 119

Баймаханова Д.М., Оспанова Д.А. Конституциялық-құқықтық сана - конституционализмнің маңызды

компоненті ретінде және оның адам құқықтары мәселелерін шешудегі рөлі................................................................. 126

Имангожина 3.А. Сланцевая революция: глобальный тренд на мировом энергетическом рынке............................. 137

Ракаева А.Н., Жуматаева Б.А., Успамбаева М.К., Доскалиева Б.Б. Экологиялық есеп қазақстандағы кәсіпорын экономикасының даму кезеңі ретінде

Нуржанова Г.И. Экономиканың аграрлық секторындағы еңбек әлеуетіне демографиялық фактордың әсері............ 147

Оспанова Д.А., Баймаханова Д.М. Қазақстан Республикасының кибер кеңістігін дамыту жағдайында мемлекеттік қызметтерді цифрландыруда әкімшілік-құқықтық қамтамасыз ету ................................................................................... 152

Pblсnекова М.О., Тлесова Э.Б., Хаитбаева Ф.К. Қазақстандағы тұрғын үй-коммуналдық шаруашылық қызметін

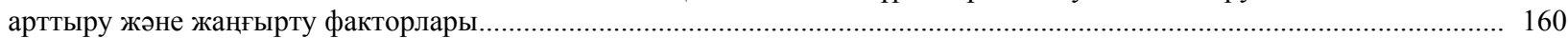

Султанова Г. Т. Аграрлық сектордың экспорттық әлеуетін дамытуға бағытталған үрдістер мен басымдықтар........ 166 


\section{СОДЕРЖАНИЕ}

Алтыбаева С.М., Сагындыков Е.С. Культурный код и мифопоэтическое моделирование в структуре художественного текста.

Сембиева Л.М., Мажитов Д.М., Карпиикая М.Е., Хамитова Д.М. Трансформация монетарной системы стран

ЕАЭС в условиях модернизации экономики.............................................................................................................

Кулсариева А.T., Султанова М.Э., Шайгозова Ж.Н. Фольклор и идентичность: история, память и мифотворчество

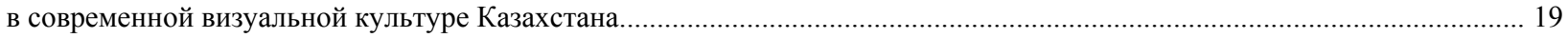

Кенжебаев Д.А. Полигон Сарышаган - краткий исторический анализ................................................................ 26

Абдулина Г.А., БазарбаевА.Г. Современные концепции управления человеческми ресурсами в организациях........... 33

Агыбаев А.Н., Адибаева А.К. Имплементационные механизмы Конвенции ООН о геноциде в уголовных

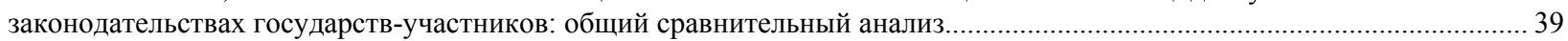

Ахметжанов Б., Тажибекова К.Б., Шаметова А.А. Анализ развития угольной промышленности Казахстана........... 44

Аюпова 3.К., Кусаинов Д.У.Проблемы конституционно-правового развития республики Казахстан в условиях

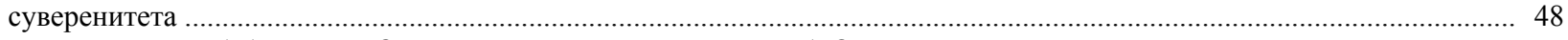

Нурпеисова А.А., Рей И.Ю., Бижанов Д.Т., Тлеужанова Д.А. Основные элементы управления процессом создания

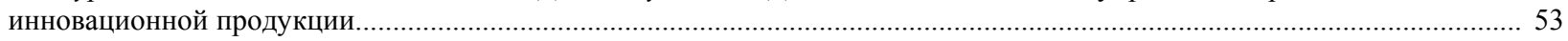

Гиздатов Г.Г. Психолингвистическое исследование концептов казахстанского дискурса...................................... 57

Ищанова Р.К. Управление государственными расходами - как обеспечение финансовой устойчивости государства. 64

Мадымева А.М. Бикенова А.С., Елеусиз Л.Т. Туристские услуги в сфере образования........................................... 68

Ескалиева А. Ж., Баймуханова М.Т., Ахмурзина Д.О. Перспективы усиления качества человеческого капитала

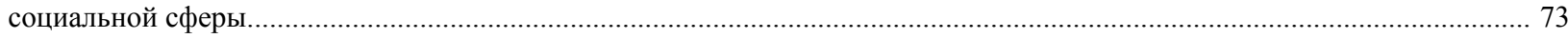

Мархаева Б.А., Козбахова Д.Л. Центр ответственности и трансфертное ценообразование..................................... 79

Сабирова Р.К., Утепкалиева К.М., Кабаков С.Б. Экологические аспекты экономики сельского хозяйства

в Казахстане........................................... 85

Тлесова Э., Хойч А., Кураш Н. Научно-инновационный потенциал республики Казкастан и его перспективы............ 89

Хамитхан Н. Межбанковская конкуренция в условиях повышения качества банковских услуг в Казахстане.............. 95

Шалдарбеков К.Б., Муханова Г.С., Нурмухамбетова 3.С. Зарубежный опыт применения проектного управления

при реализации программ развития регионов

Каратаева А.М., Бердиярова Ж.С. Этическая культура и правовая культура государственных служащих

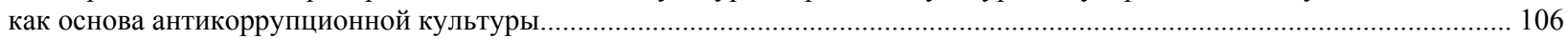

Алдабергенова А.А. Лингвокультурологические аспекты перевода литературы абсурда.......................................... 113

Стукач В. Ф., Байдалинова А. С., Сандыбаева Б. А. Казахстанская финансовая безопасность.................................... 119

Баймаханова Д.М., Оспанова Д.А. Конституционно-правовое сознание как важный компонент конституционализма

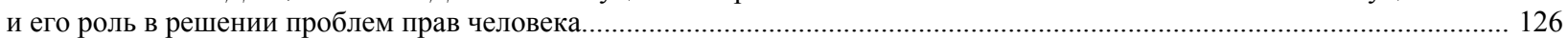

Имангожина 3.A. Сланцевая революция: глобальный тренд на мировом энергетическом рынке............................. 137

Ракаева А.Н., Жуматаева Б.А., Успамбаева М.К., Доскалиева Б.Б. Экологический учет как ступень развития

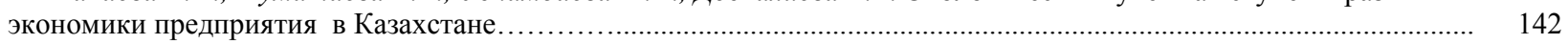

Нуржанова Г.И. Влияние демографического фактора на трудовой потенциал аграрного сектора экономики............ 147

Оспанова Д.А., Баймаханова Д.М. Административно-правовое обеспечение цифровизации государственных услуг

в условиях развития кибер пронстранства республики Казахстан..

Pыспекова М.О., Тлесова Э.Б., Хаитбаева Ф.К. Факторы инновационной модернизации и совершенствования

деятельности жилищно-коммунального хозяйства в Казахстане.

160

Султанова Г. Т. Тенденции и приоритеты развития экспортного потенциала аграрного сектора................................ 166 


\section{CONTENTS}

Altybayeva S.M., Sagyndykov E.S. Cultural code and myth poetic modeling in the structure of the artistic text..................... 5 Sembiyeva L.M., Mazhitov D.M., Karpitskaya M.E., Khamitova D.M. Transformation of the monetary system of the eurasian economic UNION countries in the conditions of modernization of the economy......

Kulsarieva A.T., Sultanova M.E., Shaigozova Zh.N. Folklore and identity: history, memory and myth-making in the modern

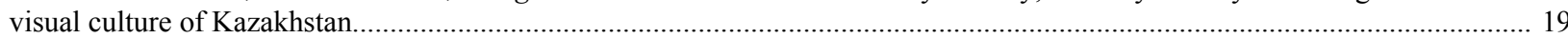

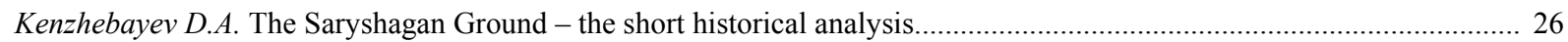

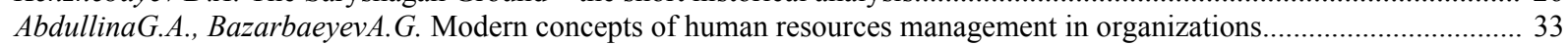

Agybayev A.N., Adibayeva A.K. Implementing mechanisms of the UN Convention on genocide in the criminal legislation

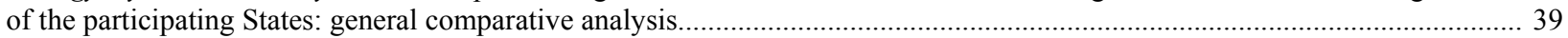

Akhmetzhanov B., Tazhibekova K.B, Shametova A.A. Analysis of development of the coal industry of Kazakhstan.............. 44 Ayupova Z.K., Kussainov D.U. Problems of constitutional and legal development of the republic of kazakhstan in the conditions of sovereignty......

Nurpeisova A.A., Rey I.Yu., Bizhanov D.T., Tleuzhanova D.A. Main elements of managing the process of creating innovation production.

Gizdatov G.G. Psycholinguistic study of the concepts of Kazakhstar

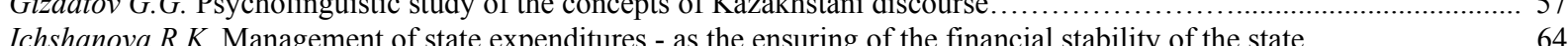

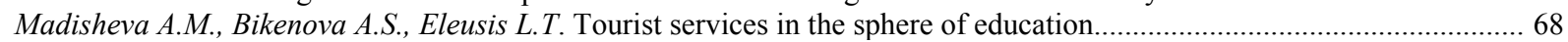

Eskalieva A. Zh., Baymukhanova M.T., Ahmurzina D.O. Perspectives of strengthening the quality of the human capital

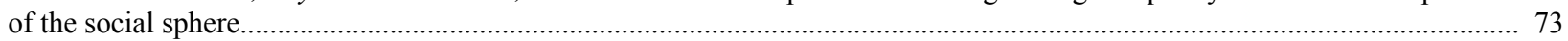

Markhayeva B.A., Kozbakhova D.L. A responsibility center and transfer pricing ................................................. 79

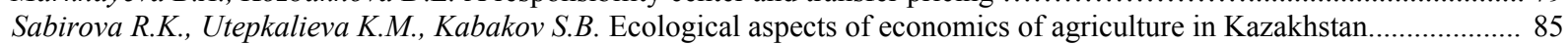

Tlessova E., Khoich A., Kurash N. Scientific innovation potential of the republic of Kazkahstan and its perspectives........ 89

Hamitkhan $N$. Interbank competition in conditions of improving the quality of banking services in Kazakhstan.................. 95

Shaldarbekov K., Mukhanova G., Nurmukhambetova Z. International practices in project management in implementing

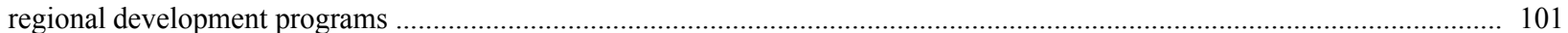

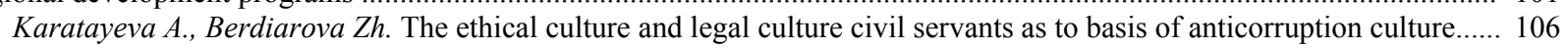

Aldabergenova A.A. Linguocultural aspects of translation of absurd literature.............................................................. 113

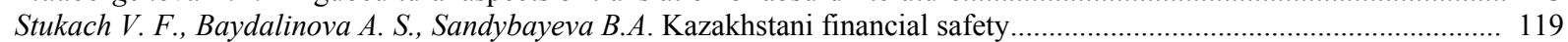

Baimakhanova D.M., Ospanova D.A. Constitutional and legal consciousness as an important component of constitutionalism

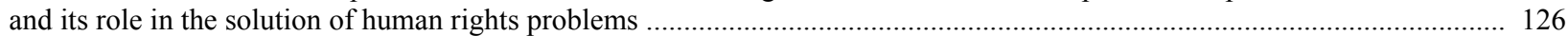

Imangozhina Z.A. Shale gas revolution: global trend in the world energy market..................................................... 137

Rakaeva A.N., Zhumataeva B.A., Uspanbayeva M.K., B.B.Doskalieva. Level of ecological report development in the economic of Kazakhstan's companies.

Nurzhanova G.I. Impact of demographic factors on labor potential of economy's agricultural sector

Ospanova D.A., Baimakhanova D.M. Administrative and legal support of digitalization of public services in the context of the development of cyber space in the republic of Kazakhstan....

Ryspekova M.O., Tlessova E.B., Khaitbayeva F. Factors of innovative modernization and improvement of activity

of housing and communal services in Kazakhstan.

Sultanova G. T. Trends and priorities for the development of export potential of the agrarian sector. 


\title{
PUBLICATION ETHICS AND PUBLICATION MALPRACTICE IN THE JOURNALS OF THE NATIONAL ACADEMY OF SCIENCES OF THE REPUBLIC OF KAZAKHSTAN
}

For information on Ethics in publishing and Ethical guidelines for journal publication see http://www.elsevier.com/publishingethics and http://www.elsevier.com/journal-authors/ethics.

Submission of an article to the National Academy of Sciences of the Republic of Kazakhstan implies that the work described has not been published previously (except in the form of an abstract or as part of a published lecture or academic thesis or as an electronic preprint, see http://www.elsevier.com/postingpolicy), that it is not under consideration for publication elsewhere, that its publication is approved by all authors and tacitly or explicitly by the responsible authorities where the work was carried out, and that, if accepted, it will not be published elsewhere in the same form, in English or in any other language, including electronically without the written consent of the copyrightholder. In particular, translations into English of papers already published in another language are not accepted.

No other forms of scientific misconduct are allowed, such as plagiarism, falsification, fraudulent data, incorrect interpretation of other works, incorrect citations, etc. The National Academy of Sciences of the Republic of Kazakhstan follows the Code of Conduct of the Committee on Publication Ethics (COPE), and follows the COPE Flowcharts for Resolving Cases of Suspected Misconduct (http://publicationethics.org/files/u2/New Code.pdf). To verify originality, your article may be checked by the originality detection service Cross Check http://www.elsevier.com/editors/plagdetect.

The authors are obliged to participate in peer review process and be ready to provide corrections, clarifications, retractions and apologies when needed. All authors of a paper should have significantly contributed to the research.

The reviewers should provide objective judgments and should point out relevant published works which are not yet cited. Reviewed articles should be treated confidentially. The reviewers will be chosen in such a way that there is no conflict of interests with respect to the research, the authors and/or the research funders.

The editors have complete responsibility and authority to reject or accept a paper, and they will only accept a paper when reasonably certain. They will preserve anonymity of reviewers and promote publication of corrections, clarifications, retractions and apologies when needed. The acceptance of a paper automatically implies the copyright transfer to the National Academy of sciences of the Republic of Kazakhstan.

The Editorial Board of the National Academy of sciences of the Republic of Kazakhstan will monitor and safeguard publishing ethics.

Правила оформления статьи для публикации в журнале смотреть на сайте:

$$
\begin{gathered}
\text { www:nauka-nanrk.kz } \\
\text { social-human.kz }
\end{gathered}
$$

\author{
Редакторы М.С. Ахметова, Т.А. Апендиев, Д.С. Аленов \\ Верстка на компьютере А.М. Кульгинбаевой \\ Подписано в печать 10.10.2018 \\ Формат 60x881/8. Бумага офсетная. Печать - ризограф. \\ 11,6 п.л. Тираж 500. Заказ 5.
}

